\title{
Body, gender and sexuality in teacher training: a meta-analysis ${ }^{1}$
}

\section{Corpo, gênero e sexualidades na formação docente: uma meta-análise}

\author{
Alfrancio Ferreira Dias ${ }^{2}$ \\ Simone Amorim ${ }^{3}$
}

\begin{abstract}
This paper aims at systematizing the specific literature on body, gender, sexuality and education, identifying the methodological process that produced the different explanation patterns found. Methodologically, introducing the meta-analysis as a research technique in Human Sciences, we intended to contribute to the construction of a literature review in a systematic way in order to guarantee the increase in accumulation and the reliability of the production of scientific knowledge. It was found that, regardless of the type of research used (Case Studies, Small N Studies, Large N Studies) and effect found (Nsig, Sig and Mixed Results), one feature is common among the analyzed studies regarding body, gender, sexuality and teacher training: the fact that all (with varying degrees of intensity) suggest that the thematic approach contributes to the destabilization of norms, ratings and rankings in the field of education.
\end{abstract}

Keywords: body; teacher training; gender; sexuality.

\section{RESUMO}

O objetivo deste texto é sistematizar a literatura específica sobre corpo, gênero, sexualidades e educação, identificando o processo metodológico

DOI: $10.1590 / 0104-4060.40998$

1 Research funded by Coordenação de Aperfeiçoamento de Pessoal de Nível Superior (CAPES) and Conselho Nacional de Desenvolvimento Científico e Tecnológico (CNPq).

2 Federal University of Sergipe, São Cristovao, Sergipe, Brazil. University City Professor José Aloísio de Campos, Marechal Rondon Ave. - Rosa Elze Garden. ZIP CODE: 49100-000. E-mail:diasalfrancio@gmail.com

3 Tiradentes University, Aracaju, Sergipe, Brazil. Murilo Dantas Ave. - 300, Building F, Farolandia Campus. ZIP CODE 49032-490.E-mail: amorim_simone@hotmail.com 
que produziu os diferentes padrões de explicação encontrados. Metodologicamente, ao introduzir a meta-análise como técnica de pesquisa nas Ciências Humanas, pretendeu-se contribuir para a construção de revisão de literatura de forma sistematizada para que se garanta o aumento da acumulação e a confiabilidade da produção do conhecimento científico. Verificou-se que, independente do tipo de pesquisa utilizado (Case Studies, Small N Studies, Large N Studies) e do feito encontrado (Nsig, Sig e Mixed Results), uma característica é comum entre os estudos analisados relativos às temáticas sobre corpo, gênero, sexualidades e formação docente: o fato de que todos (com maior ou menor grau de intensidade) sugerem que a abordagem das temáticas contribui para a desestabilização de normatizações, classificações e hierarquizações no campo da educação.

Palavras-chave: corpo; formação docente; gênero; sexualidade.

\section{Introduction}

The thematic approach regarding body, gender and sexuality has been a challenge for researchers of Human Sciences, particularly, from the Education field. Involuntarily, issues are introduced in schools, by male and female students, proposing new ways of thinking and acting, for teachers and professors. We know that several studies and surveys show that the main difficulties of introducing these issues in the school curriculum is basically the lack of familiarity and specific training in body, gender and sexuality, both initial and ongoing.

This fact is reflected in the production of scientific knowledge, to the extent that research on body, gender and sexuality has gained greater visibility in the Human Sciences, in recent decades, from a formative movement of new researchers in this field, added to the opening of universities to the dialogue with new emerging themes of social relations.

With so much scientific production in studies of body, gender and sexuality, a new challenge appears to the researchers of Human Sciences, while carrying out the planning of a research design: how to perform a less narrative literature review in the Human Sciences, creating criteria of inclusion / exclusion selection of work produced in Brazil to increase the reliability of the results? This question has been, for some time, discussed by researchers of the Studying Center and Interdisciplinary Research on Women and Gender Social Relations (NEPIMG/UFS). In this sense, by means of introducing the meta-analysis as a research technique in Human Sciences, we aim at contributing to the construc- 
tion of literature review in a systematic way in order to guarantee the increase in accumulation and the reliability of the production of scientific knowledge.

Our goal was to systematize, in methodological terms, the specific literature on body, gender, sexuality and education, identifying the methodological process that produced the different explanation patterns found in this literature to the introduction of these issues in teacher education, aiming at the destabilization of norms, classifications and hierarchies.

\section{The development of the meta-analysis}

The meta-analysis has helped researchers advance in the production of knowledge in a systematic way, from the establishment of procedures that guide the results of the studies produced in an area of knowledge (FIGUEIREDO FILHO et al., 2014). In this sense, a meta-analysis can "[...] place different studies together in one database and use analytical and statistical methodologies to explain the variance of the results using common factors to the studies" (ROSCOE; JENKINS, 2005, p. 54), and a methodological procedure "[...] synthesizes a certain amount of findings at a specific field" (FIGUEIREDO FILHO et al., 2014, p. 209). Specifically in the area of education, the meta-analysis can contribute to the concentration of results of several other studies in the same work, increasing reliability and revealing the status of a research problem, since most of the literature review is narrative and without the adoption of specific script analysis, which weakens the results.

The increase in the production of knowledge depends on how we accumulate information on a specific subject, this being the main inability of researchers to gather, process and synthesize different research results (GLASS; MCGAW; SMITH, 1981; FIGUEIREDO FILHO et al., 2014). In this perspective, the scientific researches of literature review are marked by the absence of a system that guarantees objectivity and the increase of the researched sources.

It starts with the premise that Human Sciences can advance much with the use of meta-analysis as a statistical technique to analyze a large amount of published research, comparing their results and contributing to the production of knowledge in a systematic and objective way. Methodologically, a systematic review with meta-analysis may have different strategies, from some specific features, such as area of knowledge, the place of research and what you want to search. 
However, in this study, we chose to use the planning developed by Cooper (2010) used in political science (FIGUEIREDO FILHO et al., 2014) in seven stages: identification and formulation of the research problem; collection of literature (books, articles, theses, papers, unpublished articles, etc.); collection of information from each study; assessing the quality of studies; analysis and synthesis of the studies' results; interpretation of the collected data; presentation of search results.

In the research, we analyzed which contributions addressing the issues of body, gender and sexuality in teacher education for the destabilization of norms, classifications and hierarchies are involved with the theme. The selected variables were: (1) name of the journal; (2) qualis of the journal; (3) type of research design; (4) type of effect. For the literature data collection, we used the exclusion / inclusion criteria: (1) publication in articles; (2) databases from the Scientific Electronic Library Online - SciELLO; (3) publication period between 2010-2014; (4) Human Sciences area (Education subarea); (5) articles without language restrictions; (6) Keywords: gender and education, body and education, sexuality and education; (7) type of research. With regard to the information collection for each study, we used: (1) the number of examined cases; (2) type of techniques used; (3) main results. The adoption of these criteria aimed at reducing the probability of a little influential study to be analyzed during the research, due to the possibility of publication as an article being available to a wide audience, as well as the analysis of empirical researches. Thus, it appears that 23 articles met all pre-established criteria, with a percentage of $38.65 \%$ of the articles published in the field of education. Table 1 presents the frequency of articles by journal.

TABLE 1 - FREQUENCY OF ARTICLES BY JOURNAL

\begin{tabular}{lcr}
\hline Journal & N & \% \\
\hline Cadernos Cedes & 2 & 8.69 \\
Cadernos Pagu & 1 & 4.34 \\
Cadernos de Pesquisa & 1 & 4.34 \\
Ciência \& Educação & 1 & 4.34 \\
Educação \& Realidade & 3 & 13.03 \\
Educação e Pesquisa & 1 & 4.34 \\
Educação em Revista & 1 & 4.34 \\
Educar em Revista & 5 & 21.74 \\
Pro-posições & 2 & 8.69 \\
Psicologia em Estudo & 1 & 4,34 \\
Revista Estudos Feministas & 3 & 13.04 \\
Revista Brasileira de Educação & 1 & 4.34 \\
Revista da Escola de Enfermagem da USP & 1 & 4.34 \\
\hline Total & $\mathbf{2 3}$ & $\mathbf{1 0 0}$ \\
\hline
\end{tabular}

Source: Elaborated by the authors, 2015. 
Once we disaggregated the research sample by each journal, it was observed that the production on body, gender and sexuality is spread over various journals, and the publication entitled Educar em Revista was the one that had the highest concentration of articles, a total of five, that is, $21.74 \%$ of the total analyzed, followed by Educação \& Realidade and Estudos Feministas, with $13.03 \%$ and three articles. Cadernos Cedes and Pro-posições both had 8.69\% and two published articles.

On the other hand, eight journals were cited with only one publication, which are: Pagu, Cadernos de Pesquisa, Ciência \& Educação, Educação e Pesquisa, Educação em Revista, Revista Brasileira de Educação, Revista da Escola de Enfermagem da USP and Psicologia em Estudo. Another important aspect of the systematic review was the presentation of these publications by Qualis / CAPES.

TABLE 2 - DISTRIBUTION OF PUBLICATIONS BY QUALIS/CAPES, EDUCATION FIELD

\begin{tabular}{lcc}
\hline Qualis/CAPES & N & $\mathbf{\%}$ \\
\hline A1 & 14 & 60.88 \\
A2 & 7 & 30.44 \\
B3 & 1 & 4.34 \\
C & 1 & 4.34 \\
\hline Total & $\mathbf{2 3}$ & $\mathbf{1 0 0}$ \\
\hline
\end{tabular}

Source: Elaborated by the authors, 2015.

In the evaluation process of the journal qualification, various criteria on the quality of the productions are considered. From the articles analyzed, 91.32\% were published in Qualis A1 and A2, respectively 14 articles (60.88\%) and seven articles $(30.44 \%$ ), with more than $90 \%$ of the publications. Thus, it is understood that the higher the qualification of the magazine, the greater will also be the requirements of publication quality. With 4.34\%, two magazines are evaluated with B3 and C, respectively, in the education field, disregarding the evaluation of other areas of knowledge.

Soon after we located the journals and Qualis that had, in the Education field, the variable of greatest interest, we had the type of research design. We then tried to analyze what methodology (quantitative and qualitative) the authors used in their studies so that we could identify the methodological planning about the studies on body, gender and sexuality in teacher education. Table 3 shows the distribution of research. 
TABLE 3 - FREQUENCY OF THE TYPE OF METHODOLOGY

\begin{tabular}{lcc}
\hline Methodology & N & \% \\
\hline Quantitative & 1 & 4.34 \\
Qualitative & 20 & 86.97 \\
Both & 2 & 8.69 \\
\hline Total & $\mathbf{2 3}$ & $\mathbf{1 0 0}$ \\
\hline
\end{tabular}

Source: Elaborated by the authors, 2015.

The majority of studies used, essentially, the qualitative methodology (86.97\%) comprising the studies of Seffner (2011); Costa and Ribeiro (2011); Wenetz (2012); Ferrari and Almeida (2012); Silva and Luz (2010); Altman, Ayoub and Amaral (2011); Dornelles and Pocahy (2014); Reis and Paraíso (2013); Quirino and Rocha (2012, 2013); Pinto (2011); Torres and Prado (2014); Xavier Filha (2012); Silva and Soares (2014); Avila, Toneli and Andaló (2011); Alonso and Zurbriggen (2014); Ehrenberg (2014); Richter and Vaz (2010); Dornelles (2012); Moizés and Bueno (2010). This result can be explained by the variables used by the researchers as well as due to the tradition of research in the Human Sciences, especially in education, to use qualitative methodology in the studies.

However, it is observed that $8.69 \%$ of the studies (RABELO, 2013; TEIXEIRA FILHO; RONDINI; BESSA, 2011) have the combination of both approaches and 4.34\% (SOUZA; DINIS, 2010) used the quantitative only. As most studies took advantage of the qualitative methodology, we tried to find out which qualitative techniques were used to collect data. The main results are shown in Table 4 below.

TABLE 4 - FREQUENCY OF QUALITATIVE TECHNIQUES

\begin{tabular}{lcc}
\hline Technique & N & $\mathbf{\%}$ \\
\hline Ethnography & 5 & 21.74 \\
Interview & 8 & 34.81 \\
Focus group & 1 & 4.34 \\
Research-action & 2 & 8.69 \\
Questionnaires & 4 & 17.39 \\
Workshops & 2 & 8.69 \\
Field Report & 1 & 4.34 \\
\hline Total & $\mathbf{2 3}$ & $\mathbf{1 0 0}$ \\
\hline
\end{tabular}

Source: Elaborated by the authors, 2015. 
The most used technique was the "interview" with $34.82 \%$ of cases in eight studies (COSTA; RIBEIRO, 2011; SILVA; LUZ, 2010; TORRES; PRADO, 2014; QUIRINO; ROCHA, 2012; AVILA; TONELI; ANDALÓ, 2011; ALONSO; ZURBRIGGEN, 2014; EHRENBERG, 2014; DORNELLES, 2012). Then, five studies $(21.74 \%)$ used the ethnography technique (SEFFNER, 2011; WENETZ, 2012; REIS; PARAÍSO, 2013; QUIRINO; ROCHA, 2013; RICHTER; VAZ, 2010) and three studies (13.03\% ) made use of questionnaires (SOUZA; DINIS, 2010; ALTMAN; AYOUB; AMARAL, 2011; TEIXEIRA FILHO; RONDINI; BESSA, 2011). Research-action and workshops were used in two studies each (8.69\%), respectively in the studies: Xavier Filha (2012); Moizés and Bueno (2010); Pinto (2011); Silva and Soares (2014). Finally, the focus group and the field report were used as qualitative technique in one (4.34\%) study each: Dornelles and Pocahy (2014) and Ferrari and Almeida (2012).

It is inferred that the studies have a variety of qualitative techniques, differentiating the intensity of use considering the reality of the investigated techniques. This suggests that, for investigations on issues of body, gender and sexuality in the education field, the integration of qualitative and quantitative methodologies can strengthen the type of research design and provide more solid and systematic answers to research problems, expanding quality and the impact of research in the specific scientific field and in the production of specific knowledge.

To identify the level of abstraction of the analyzed studies, we used the prospect of Figueiredo Filho (2009), that defines its analytical dimension in Case Studies $(\mathrm{N}=1)$ and low level of abstraction, Small $N$ Studies $(\mathrm{N}<20)$ and moderate level of abstraction and Large $N$ Studies $(\mathrm{N}>50)$ with a high level of abstraction.

Specifically, Small N Studies are the ones that have analyzed less than 20 participants and Large N Studies are the ones that had more than 50 participants. As for the Case Studies, it was not necessary to reclassify the category, since it refers to an intensive study of a specific reality, which affects the applicability of this category in other qualitative research, pointing out the casualties to generalize for categories of analysis (FIGUEIREDO FILHO et al., 2014). The use of historical-organizational case studies (TRIVIÑOS, 1987; YIN, 2005) in some of the cases is justified based on the understanding of the themes of body, gender and sexuality at the micro-level (in the particularities of the researched educational institutions) in order to relate it to the macro-level (policies and regional, national and international educational strategies). The concern with this argument lies in the fact that five analyzed articles (21.74\%) use case studies (SOUZA; DINIS, 2010; ALTMAN; AYOUB; AMARAL, 2011; REIS; PARAÍ- 
SO, 2013; SILVA; SOARES, 2014; TEIXEIRA FILHO; RONDINI; BESSA, 2011), as can be seen in Table 5.

TABLE 5 - FREQUENCY OF ARTICLES BY TYPE OF RESEARCH DESIGN

\begin{tabular}{lcc}
\hline Landman & N & $\mathbf{\%}$ \\
\hline Case Studies & 5 & 21.74 \\
Small N Studies & 12 & 52.18 \\
Large N Studies & 6 & 26.08 \\
\hline Total & $\mathbf{2 3}$ & $\mathbf{1 0 0}$ \\
\hline
\end{tabular}

Source: Elaborated by the authors, 2015.

As shown in Table 5, 52.18\% of the articles produced are composed of studies with few cases (Small N Studies) (SEFFNER, 2011; COSTA; RIBEIRO, 2011; FERRARI; ALMEIDA, 2012; SILVA; LUZ, 2010; DORNELLES; POCAHY, 2014; PINTO, 2011; TORRES; PRADO, 2014; QUIRINO; ROCHA, 2012; AVILA; TONELI; ANDALÓ, 2011; ALONSO; ZURBRIGGEN, 2014; DORNELLES, 2012; MOIZÉS; BUENO, 2010). With a lower incidence, we identified the Large $N$ Studies in $26.08 \%$ of the studies, a total of six articles (WENETZ, 2012; RABELO, 2013; QUIRINO; ROCHA, 2013; XAVIER FILHA, 2012; EHRENBERG, 2014; RICHTER; VAZ, 2010). It is inferred from these results, that it is not possible to generalize the results found in the case study of literature, given the advantages and disadvantages that this method holds.

However, the case study may be relevant to the knowledge of concrete situations with the investigated. Thus, in accordance with the scheme of social relationships observed, we can point out elements that can inform analysis that contribute to a better understanding of the themes of body, gender and sexuality, when incorporated with other quantitative and qualitative methods to strengthen the type of research design as those shown in the Small N Studies and Large N Studies.

The sixth variable concerns the significance of the results found in the literature selected for this meta-analysis on body, gender and sexuality in teacher education. Therefore, we use the work model by Figueiredo Filho et al. (2014, p. 55), which subdivides the analysis of this variable in Sig (those with findings suggesting that the approach of body, gender and sexuality issues in teacher education contribute to the destabilization of norms, classifications and hierarchies involving the theme); Nsig (articles that claim that the inclusion of these issues in teacher education and development of a non-discriminatory education are independent); Mixed Results (studies that found "significant and no significant effects associated with more controversial and inconclusive inferences"). In Table 6 you can see the frequency of articles by type of effect. 
TABLE 6 - FREQUENCY OF ARTICLES BY TYPE OF EFFECT

\begin{tabular}{lcc}
\hline Type of Effect & N & \% \\
\hline Nsig & 5 & 21.74 \\
Sig & 14 & 60.87 \\
Mixed Results & 4 & 17.39 \\
\hline Total & $\mathbf{2 3}$ & $\mathbf{1 0 0}$ \\
\hline
\end{tabular}

Source: Elaborated by the authors, 2015.

It can be observed that in the researched literature, the results are statistically significant in $60.87 \%$ of production, totaling 14 articles (SEFFNER, 2011; WENETZ, 2012; RABELO, 2013; ALTMAN; AYOUB; AMARAL, 2011; DORNELLES; POCAHY, 2014; PINTO, 2011; TORRES; PRADO, 2014; QUIRINO; ROCHA, 2012; XAVIER FILHA, 2012; SILVA; SOARES, 2014; ALONSO; ZURBRIGGEN, 2014; EHRENBERG, 2014; DORNELLES, 2012; MOIZÉS; BUENO, 2010). In this perspective, the status of more than $60 \%$ of the produced literature on the subject suggests that the approach of the themes of body, gender and sexuality in teacher education contributes to the destabilization of norms, classifications and hierarchies surrounding the subject.

However, $21.74 \%$ of production research on the subject found no significant results that the inclusion of the themes of body, gender and sexuality in teacher education contributes to the destabilization of norms, classifications and hierarchies involving the issue (COSTA; RIBEIRO, 2011; SILVA; LUZ, 2010; REIS; PARAÍSO, 2013; AVILA; TONELI; ANDALÓ, 2011; TEIXEIRA FILHO; RONDINI; BESSA, 2011). Finally, we also note that $17.39 \%$ of the articles produced in the literature suggest mixed results, in which the insertion of these themes exerts influences sometimes not related to the process of destabilization of norms, classifications and hierarchies involving the issue (SOUZA; DINIS, 2010; FERRARI; ALMEIDA, 2012; QUIRINO; ROCHA, 2013; RICHTER; VAZ, 2010). In Chart 1 we summarize the conditions of these variables. 
CHART 1 - CONDITIONS IN WHICH THE INSERTION OF THEMATIC ISSUES INFLUENCES ON TEACHER EDUCATION

\begin{tabular}{|l|l|}
\hline \multicolumn{1}{|c|}{ Authors/year } & \multicolumn{1}{c|}{ Arguments } \\
\hline $\begin{array}{l}\text { Seffner (2011), Dornelles } \\
\text { and Pocahy (2014), Pinto } \\
(2011) .\end{array}$ & $\begin{array}{l}\text { The thematic of body, gender and sexuality appears } \\
\text { unpredictably in the classroom. }\end{array}$ \\
\hline $\begin{array}{l}\text { Wenetz (2012), Dornelles } \\
(2012) .\end{array}$ & $\begin{array}{l}\text { The school is an institution where meanings are disputed, } \\
\text { accepted, rejected and imposed through processes in which } \\
\text { agents are inserted, participating in cultural negotiations or } \\
\text { very complex demands. }\end{array}$ \\
\hline $\begin{array}{l}\text { Rabelo (2013), Torres and } \\
\text { Prado (2014). }\end{array}$ & $\begin{array}{l}\text { The power of the new voices shows that discrimination of } \\
\text { roles related to gender in education are caused by social } \\
\text { forces, but there may be a resistance to these determinations, } \\
\text { resistance based on the success of transsexuals and } \\
\text { transvestites becoming teachers. }\end{array}$ \\
\hline $\begin{array}{l}\text { Altman, Ayoub and Amaral } \\
\text { (2011), Moizés and Bueno } \\
\text { (2010). }\end{array}$ & $\begin{array}{l}\text { Aspects connected to the thematic of body, gender and } \\
\text { sexuality are considered during teachers' lesson planning, } \\
\text { with the consequent formation of a livable existence at } \\
\text { school, which is constituted as a powerful direction for the } \\
\text { flight of the joint paths between markers. }\end{array}$ \\
\hline $\begin{array}{l}\text { Quirino and Rocha (2012), } \\
\text { Ehrenberg (2014). }\end{array}$ & $\begin{array}{l}\text { The recognition by the teachers of their conceptual } \\
\text { limitations and availability for training, which demonstrates } \\
\text { the sensitivity to question the discussion of sexuality at } \\
\text { and Soares (2014), Alonso } \\
\text { and Zurbriggen (2014). } \\
\text { implemented. }\end{array}$ \\
\hline $\begin{array}{l}\text { School agents are open-minded to the construction of } \\
\text { new ways to make sense of body issues, gender, sexuality } \\
\text { and the many possibilities of setting up masculinity and } \\
\text { femininity, since they are urged to think and to demonstrate } \\
\text { strangeness about what is proposed as natural. }\end{array}$ \\
\hline
\end{tabular}

Source: Elaborated by the authors, 2015.

From the arguments made, it can be said that the inclusion of body, gender and sexuality issues is consolidating as one of the main topics of debates in the Human Sciences, showing its place in the production of knowledge. As for education, the implementation of the contribution of the themes of body, gender and sexuality in teacher education is linked to a new scenario of training public policies and openness to discussion of these issues in schools, questioning the "place" and "lack of place" of body and gender relations and sexual diversity, from the senses and cultural meanings.

It is believed here that social interactions and the identification processes destabilize, change and re-signify the norms, classifications and hierarchies in 
the course of changes in the relationship of time and space, influencing the way we conduct and work with these issues in basic education.

\section{Final considerations}

Our intention with this research was to bring to the field of education some aspects worked on a systematic review and meta-analysis, because much of the review methodology is predominantly being developed in the area of Health Sciences, and the Human Sciences being inserted in Political Science and Social Sciences. Among the expected results of the meta-analysis, there is a greater orientation of the actions to be developed during the research so that the result of a literature review is systemic, contributing to greater accumulation of knowledge in a specific area.

To systematize, methodologically, the specific literature of the subject body, gender, sexuality and teacher education, we also identified certain characteristics in brief: (1) Most of the production has been published in journals of Education (52.18\%), followed by Social Sciences (39.13\%) and Health Sciences (8.69\%); (2) Most were written between the years 2011 and 2012 (44.82\%); (3) The studies were published in journals with evaluation of Qualis / CAPES in A1 and A2 (91, 32\%); (4) The majority of studies essentially used qualitative methodology $(86.97 \%)$, noting that $8.69 \%$ of the studies show the combination of qualitative and quantitative methodology; (5) The most used qualitative methodology technique was the interview with $34.82 \%$ of cases, and we noted the absence of participant observation as a qualitative technique; (6) It was found that $60.87 \%$ of the literature produced statistically significant results which means the inclusion of the subject to destabilization; (7) $52.18 \%$ of the articles produced are composed of few case studies (Small N Studies) with up to 30 participants.

Therefore, it can be inferred that regardless of the type of research used (Case Studies, Small N Studies, Large N Studies) and the result found (Nsig, Sig and Mixed Results), a feature is common among the studies analyzed about themes related to body, gender, sexuality and teacher training, the fact that all (some to a greater degree than others) suggest that the thematic approach contributes to the destabilization of norms, ratings and rankings in the field of education.

It is understood that it is necessary to make a dialogue among studies on body, gender and sexuality, in the Human Sciences, in particular in the field of education, since only then we can understand that they are interconnected 
and that we can hardly understand them separately in teacher training. There is the need to make more efficient reading of these issues, to question the social representation of identities and sexual gender, as well as the spaces that they are assigned to, because we know that "[...] gender identities are part of the culture and are set by the ways we use our bodies discursively" (GOMES, 2013, p. 14).

It is precisely on the need to think about body cultural construction that we need to reflect. We have to take into account the bodies fleeing or moving away from the binary discourse of male / female. Otherwise, these bodies will not be legitimated, challenged and, in many cases excluded, as the construction of gender form the body becomes excluding and promotes the formation of an "abject", "strange", "excentric", not "civilized being" (DIAS, 2014).

Thus, the limits of gender construction should also include the bodies in borders or beyond the male / female opposition, so that, in the process, we can discuss and deconstruct body images stereotyped by society and its reproduction in the daily school. The path to this is the degree in which these discussions are included in training courses for teachers.

\section{REFERENCES}

ALONSO, G. B.; ZURBRIGGEN, R.Transformando corporalidades: desbordes a la normalidad pedagógica. Educar em Revista, Curitiba, Edição Especial n. 1, p. 53-69, 2014.

ALTMAN, H.; AYOUB, E.; AMARAL, S. C. F. Gênero na prática docente em educação física: "meninas não gostam de suar, meninos são habilidosos ao jogar"? Revista Estudos Feministas, Florianópolis, v. 19, n. 2, p. 491-501, 2011.

AVILA, A. H.; TONELI, M. J. F.; ANDALÓ, C. S. de A. Professores/as diante da sexualidade-gênero no cotidiano escolar. Psicologia em Estudo, Maringá, v. 16, n. 2, p. 289-298, 2011.

COOPER, H. Research synthesis and meta-analysis: a step-by-step approach. 3. ed. Thousand Oaks: Sage, 2010.

COSTA, A. P.; RIBEIRO, P. R. M. R. Ser professora, ser mulher: um estudo sobre concepções de gênero e sexualidade para um grupo de alunas de Pedagogia. Revista Estudos Feministas, Florianópolis, v. 19, n. 2, p. 475-489, 2011.

DIAS, A. F. Como as escolas educam corpos nas práticas pedagógicas. Revista Tempos e Espaços em Educação, v. 7, n. 12, p. 103-112, 2014.

DORNELLES, P. G. Do corpo que distingue meninos e meninas na educação física escolar. Cadernos Cedes, Campinas, v. 32, n. 87, p. 187-197, 2012. 
DORNELLES, P. G.; POCAHY, F. A. "Prendam suas bezerras que o meu garrote está solto!" Interseccionando gênero, sexualidade e lugar nos modos de subjetivação regionais. Educar em Revista, Curitiba, Edição Especial n. 1, p. 117-133, 2014.

EHRENBERG, M. C. A linguagem da cultura corporal sob o olhar de professores da educação infantil. Pro-Posições, v. 25, n. 1 (73), p. 181-198, 2014.

FERRARI, A.; ALMEIDA, M. A. de. Corpo, gênero e sexualidade nos registros de indisciplina. Educação e Realidade, Porto Alegre, v. 37, n. 3, p. 865-885, 2012.

FIGUEIREDO FILHO, D. B. O Elo corporativo? Grupos de interesse, financiamento de campanha e regulação eleitoral. Dissertação (Mestrado em Ciência Política) - Universidade Federal de Pernambuco - UFPE, Recife, 2009.

FIGUEIREDO FILHO, D. B.; PARANHOS, R.; SILVA JÚNIOR, J. A.; ROCHA, E. C.; ALVES, D. P. O que é, para que serve e como se faz uma meta-análise? Revista Teoria $\&$ Pesquisa, v. 23, n. 2, p. 205-228, 2014.

GLASS, G.; McGAW, B.; SMITH, M. L. Meta-analysis in social research. Beverly Hills: Sage, 1981.

GOMES, C. M. Os estudos de gênero como modelo de leitura. In: DIAS, A. F.; PACHECO, A. C. L. (Orgs.). Gênero trans e multidisciplinar. Jundiaí/SP: Paco Editorial, 2013.

MOIZÉS, J. S.; BUENO, S. M. V. Understanding sexuality and sex in schools according to primary education teachers. Revista da Escola de Enfermagem da USP, v. 44, n. 1, p. 200-207, 2010.

PINTO, J. P. Ler e escrever sobre corpos: metodologia feminista para letramento de jovens. Cadernos de Pesquisa, v. 41, n. 143, p. 538-558, 2011.

QUIRINO, G. da S.; ROCHA, J. B. T. da. Sexualidade e educação sexual na percepção docente. Educar em Revista, Curitiba, n. 43, p. 205-224, 2012.

QUIRINO, G. da S.; ROCHA, J. B. T. da. Prática docente em educação sexual em uma escola pública de Juazeiro do Norte, CE, Brasil. Ciência \& Educação, Bauru, v. 19, n. 3, p. 677-694, 2013.

RABELO, A. Debates sobre gênero na docência: o professor do sexo masculino nas séries iniciais do Rio de Janeiro - Brasil e Aveiro-Portugal. Educar em Revista, Curitiba, v. 34, n. 48, p. 207-234, 2013.

REIS, C. d'Á. R.; PARAÍSO, M. A. A constituição de corpos guerreiros em um currículo escolar. Educação \& Realidade, Porto Alegre, v. 38, n. 4, p. 1243-1266, 2013.

RICHTER, A. C.; VAZ, A. F. Educar e cuidar do corpo: biopolítica no atendimento à pequena infância. Educação em Revista, Belo Horizonte, v. 26, n. 2, p. 117-134, 2010.

ROSCOE, D. D.; JENKINS, S. A meta-analysis of campaign contributions impact on roll call voting. Social Science Quarterly, v. 86, n. 1, 2005. 
SEFFNER, F. Um bocado de sexo, pouco giz, quase nada de apagador e muitas provas: cenas escolares envolvendo questões de gênero e sexualidade. Revista Estudos Feministas, Florianópolis, v. 19, n. 2, p. 561-572, 2011.

SILVA, I. de O.; LUZ, I. R. da. Meninos na educação infantil: o olhar das educadoras sobre a diversidade de gênero. Cadernos Pagu, n. 34, p. 17-39, 2010.

SILVA, R. A. da; SOARES, R. Sexualidade e identidade no espaço escolar: notas de uma atividade em um curso de educação a distância. Educar em Revista, Curitiba, Edição Especial n. 1, p. 135-151, 2014.

SOUZA, L. C.; DINIS, N. F. Discursos sobre homossexualidade e gênero na formação docente em biologia. Pro-Posições, Campinas, v. 21, n. 3, p. 119-134, 2010.

TEIXEIRA-FILHO, F. S.; RONDINI, C. A.; BESSA, J. C. Reflctions on homophobia and education in schools in the interior of Sao Paulo state. Educação e Pesquisa, São Paulo, v. 37, n. 4, p. 725-742, 2011.

TORRES; M. A.; PRADO, M. A. Professoras transexuais e travestis no contexto escolar: entre estabelecidos e outsiders. Educação \& Realidade, Porto Alegre, v. 39, n. 1, p. 201-220, 2014.

TRIVIÑOS, A. N. S. Introdução à pesquisa em ciências sociais: a pesquisa qualitativa em educação. São Paulo: Atlas, 1987.

WENETZ, I. Gênero, Corpo e Sexualidade: negociações nas brincadeiras do pátio escolar. Cadernos Cedes, Campinas, v. 32, n. 87, p. 199-209, 2012.

XAVIER FILHA, Constantina. A menina e o menino que brincavam de ser...: representações de gênero e sexualidade em pesquisa com crianças. Revista Brasileira de Educação, v. 17, n. 51, p. 627-646, 2012.

YIN, R. K. Estudo de caso: planejamento e métodos. Porto Alegre: Bookman, 2005.

Texto recebido em 21 de abril de 2015. Texto aprovado em 15 de junho de 2015. 